\title{
Customer Concerns and Future Prospects of E-Banking Services at Nationalized Banks in Tamil Nadu
}

\author{
S. Priya Durga
}

\begin{abstract}
Indian banking industry has beheld a notable business pattern by way of introducing Information Technology Enabled Services (ITES) concept in banking services. Nationalized banks in Indian banking industry are progressively playing an important role in improving the computerized banking services. This research is an attempt to identify the customers perception, concerns towards e- banking services. Further the study tries to identify the future prospects of e-banking services in South India. Data has been collected through structured questionnaire, from one hundred and fifty customers of six nationalized banks, situated in five districts of Tamil Nadu, South India. Results of the study shows that most of the customers were the users of e-banking services and identified benefits such as accessing banking services at any time \& anywhere, saving of time, easy and customized method of accessing the services. Demographic variables such as educational, occupation and income level have significant impact on the customers' preference while availing e-banking services. On the other hand, e-banking yet challenged with customer concerns like hacking of banking operations, lack of technical knowledge, network failure, and lack of customer complaint feedback mechanism.
\end{abstract}

Keywords: Customer concerns, Prospects, E-banking, Nationalized bank, Technology adoption, South India

\section{INTRODUCTION}

Banking is one among the sectors, witnessed massive benefits with the concept of Information Technology Enabled Services. With the multiplying spread of internet and computer usage, availing banking services is no longer confined to the branches of banks. E-Banking service has become ideal for banks to meet customer expectations. To distribute wide range of banking services over the past two decades, banks using various electronic and telecommunication modes like by way of internet, credit cards, ATM cum debit cards, smart phones. E-banking is one among such mode by which banks offer traditional banking services by means of convenient electronic mode. All through the world, banking industry rephrasing their business strategies and exploring new business opportunities, by offering technology enabled services. Likewise, Indian banking industry relies on technology enabled banking

Revised Manuscript Received on December 16, 2019.

* Correspondence Author

Dr.S.Priya Durga, Assistant Professor, Kalasalingam Business School, Kalasalingam Academy of Research and Education, Tamil Nadu, India. Email:priyadurgasm@gmail.com services to achieve customer satisfaction and to retain their customers with the bank. (Hasan et al, 2013).

\section{LITERATURE REVIEW}

Over the past two decades, Banks in India has remarkably moderate their operational costs and improve their customers satisfaction with the use of technology enabled services i.e., E-Banking - a broad term comprehends internet banking, online banking, mobile banking etc., has witnessed a remarkable growth in Indian banking industry [1][2], as rightly predicted by Rugimbana, there is huge potential for online banking due to its on functionality, customization and the preference to do virtual banking anytime and anywhere [3].

Further, studies shows that Indian banks will target most of the non-online banking users who may lack regular access to desktop internet but who are likely to use their mobile phones, which ultimately will create potential market of introducing mobile banking in India. Among the various e-banking modes, ATM was the most preferred technological mode adopted predominantly by customers and banks [4]. Earlier studies discussed that customers are satisfied towards e-banking services only if they are highly influenced by the factors like accessibility, awareness, and responsiveness [5], reliability/security, customized service, easy access, grievance handling, prompt service which were preferred by customers [6]. Banker must concentrate on these factors which may results in creating loyalty thereby they can retain their customers.

Studies revealed that there are plenty of customer concerns which influence their intention in adopting internet banking. Though Internet banking has derived enormous benefits to customers, it has the potential risk to create opportunities for fraud and cyber-crime by means of financial security and privacy. Throughout India, different instances of hacking report suggested that users of e- banking services need to be more careful while making online payments/ transactions. Customers are asked not to share e- banking personal information like PIN numbers, One time password (OTP) and passwords etc. with anyone, including the bank employees; change of ATM PIN and online login / fund transfer passwords on a regular basis and ensure that the online bank account is properly log out [7]. 
Lack of adequate knowledge about internet usage, non-accessible location, poor network, misuse of debit cum ATM cards and difficulty in accessing the online account are yet some of the concerns which is also significant among customers especially to the senior citizens. Education of customers towards financial and personal security risks can play a significant role for customer protection thereby; limit reputational risk of the banks in providing e-banking services [8] [9]. Likewise, with regard to the technology enabled banking services, the study results reveals that self-efficiency and trust are not positively correlated with the customers intention towards e- banking while perceived ease of use influences the intention the most [10].

Studies shows that while identifying the customers' usage of e-banking services of nationalized, private and foreign banks in India, customers identified that there is no significant difference in the perception of customers towards the facilities offered by all the banks in India [11]. Further demographic factors has significant impact on internet banking behavior, particularly with regard to occupation and age, suggested that customer's perception towards e-banking services of nationalized and private banks will help the bankers to identify the needs of customers in a better way [12].

As rightly suggested by Raghavan [13], over $85 \%$ of the completed payment transactions are electronic bank users and customers were relatively least preferred the traditional banking. By next decade, almost all the banks, including public sector and nationalized banks, would have online ATMs, Mobile banking, virtual banking, e-banking, etc., witnessed the emerging trend towards electronic delivery of banking services is occurring not only as the preferred mode consumers but also because of the increasing competitive banking business environment in the techno- global context.

\section{RESEARCH OBJECTIVES}

- To understand the perception of customers towards e-banking services offered by nationalized banks in Tamil Nadu.

- To identify the concerns of customers in availing e-banking services of nationalized banks in Tamil Nadu

- To analyse the future prospects of e-banking services of nationalized banks in Tamil Nadu

- To suggest measures for effective adoption of technology based banking services at nationalized banks in Tamil Nadu.

\section{METHODOLOGY}

\section{A. Sampling Design:}

This research study was carried out by getting responses from one hundred and fifty customers having account with any of the six nationalised banks (Bank of India, IDBI, Indian Bank, IOB, SBI and UBI) which were recognised as top nationalised banks, situated in five districts of Tamil Nadu, South India.

\section{B. Data Sources}

Using simple random sampling method, data for the research study were collected from the customers (visiting selected nationalized banks at office hours and off hours at ATM centers of the banks) using structured questionnaire.

\section{Instrument and Scale Reliability}

Measurement items of various e-banking services were identified based on the previous research studies \& the opinion from the customers (during pilot testing), which were presented in the literature review is considered for this study. The constructed questionnaire which was used to collect the data for the study consists of three major sections namely, measuring customers demographic profile, personal bank \& users profile and a set of eight dimensions which helps to identify the customers preference and the prospects of e-banking services were scaled on a five point scale ranges from "Very Weak Influence" to "Very High Influence". To test the internal consistency of items, the reliability of the scaled eight factors was determined, the Cronbach Alpha value was found to be 0.921 , shows that the questions was highly reliable.

\section{RESULTS \& DISCUSSIONS}

\section{A. Sample Composition}

From the one hundred and fifty nationalized bank customers surveyed, the composition of sample has a reasonable spread across the groups of various demographic and customers profile variables are precised in Table I.

TABLE- I Composition of Sample

\begin{tabular}{|l|l|c|}
\hline \multicolumn{1}{|c|}{$\begin{array}{c}\text { Demographic \& } \\
\text { Personal/Customers Profile }\end{array}$} & \multicolumn{1}{|c|}{$\begin{array}{c}\text { Groups of the } \\
\text { variables }\end{array}$} & $\begin{array}{c}\text { Percentage of } \\
\text { Respondents }\end{array}$ \\
\hline Gender & Male & $55 \%$ \\
\hline Age Group of customers & $25-35$ Years & $47 \%$ \\
\hline Educational Qualification & Graduate & $59 \%$ \\
\hline Occupation of customers & Business & $47 \%$ \\
\hline Income Group of customers & $\begin{array}{l}\text { Rs. 25,000 - } \\
50,000\end{array}$ & $38 \%$ \\
\hline Type of Account Holders & $\begin{array}{l}\text { Savings Bank } \\
\text { Account }\end{array}$ & $78 \%$ \\
\hline Experience in using e-banking & $1-3$ year & $39 \%$ \\
\hline $\begin{array}{l}\text { Frequency of using e-banking } \\
\text { (in a month) }\end{array}$ & $04-10$ times & $39 \%$ \\
\hline Source Primary data-SPSS &
\end{tabular}

*Source; Primary data-SPSS

Out of one hundred and fifty customers surveyed, $55 \%$ were male, $47 \%$ of the customers belong to the age group of 20-30 years of age, whereas $47 \%$ of the customers were business people and $59 \%$ of the customers were graduates. $26 \%$ of the surveyed customers are the account holders of Indian Bank, $78 \%$ of the customers were the holders of savings bank account $(78 \%)$, the customers who were most likely to have their account for 1 to 3 years (39\%) and the most of the customers use e-banking services at a frequency of 4-10 times in a month. 


\section{B.Customers Perception towards E-Banking Services}

The distribution of customers perception towards various e-banking services are summarised in below Table II.

The mean score of the surveyed customers, who were availing e-banking services (one hundred and thirty seven) were between 2.46 and 3.67. The highest mean value of 3.67 was bagged by "Online Shopping" followed by balance enquiry, message alert, fund transfer, mobile banking and payment of bills (mean value- 3.35) explains very little difference in the customers' perception among these six e-banking services.

TABLE- II Customers Perception towards E-Banking

\section{Services}

\begin{tabular}{|c|c|c|c|c|c|c|c|c|}
\hline \multirow[t]{2}{*}{ S.NO } & \multirow{2}{*}{$\begin{array}{l}\text { E-banki } \\
\text { ng } \\
\text { Services }\end{array}$} & \multicolumn{5}{|c|}{$\begin{array}{c}\text { Very Weak influence to } \\
\text { Very Strong Influence } \\
(\mathrm{N}=137) \\
\end{array}$} & \multirow{2}{*}{$\begin{array}{c}\text { Mea } \\
\text { n }\end{array}$} & \multirow[t]{2}{*}{$\boldsymbol{\sigma}$} \\
\hline & & VWI & WI & $\mathbf{N}$ & SI & $\begin{array}{c}\text { VS } \\
\text { I }\end{array}$ & & \\
\hline 1 & $\begin{array}{l}\text { Message } \\
\text { Alert }\end{array}$ & 14 & 6 & 8 & 6 & 46 & 3.55 & 1.59 \\
\hline 2 & $\begin{array}{l}\text { Balance } \\
\text { enquiry }\end{array}$ & 5 & 12 & $\begin{array}{l}1 \\
2\end{array}$ & $\begin{array}{l}5 \\
9\end{array}$ & 49 & 3.64 & 1.52 \\
\hline 3 & $\begin{array}{l}\text { Mobile } \\
\text { banking }\end{array}$ & 12 & 14 & $\begin{array}{l}3 \\
\mathbf{0}\end{array}$ & $\begin{array}{l}3 \\
1\end{array}$ & 50 & 3.36 & 1.61 \\
\hline 4 & $\begin{array}{l}\text { Fund } \\
\text { transfer }\end{array}$ & 7 & 16 & $\begin{array}{l}2 \\
0\end{array}$ & $\begin{array}{l}6 \\
2\end{array}$ & 32 & 3.38 & 1.49 \\
\hline 5 & $\begin{array}{l}\text { Payment } \\
\text { of bills }\end{array}$ & 11 & 14 & $\begin{array}{l}2 \\
7\end{array}$ & $\begin{array}{l}4 \\
2\end{array}$ & 43 & 3.35 & 1.58 \\
\hline 6 & $\begin{array}{l}\text { Foreign } \\
\text { exchange } \\
\text { transfer }\end{array}$ & 26 & 36 & $\begin{array}{l}3 \\
3\end{array}$ & $\begin{array}{l}3 \\
8\end{array}$ & 4 & 2.46 & 1.34 \\
\hline 7 & $\begin{array}{l}\text { Online } \\
\text { trading }\end{array}$ & 21 & 25 & $\begin{array}{l}4 \\
\mathbf{0}\end{array}$ & $\begin{array}{l}3 \\
5\end{array}$ & 16 & 2.74 & 1.45 \\
\hline 8 & $\begin{array}{l}\text { Online } \\
\text { shopping }\end{array}$ & 99 & 9 & $\begin{array}{l}1 \\
1\end{array}$ & $\begin{array}{l}5 \\
0\end{array}$ & 58 & 3.67 & 1.60 \\
\hline
\end{tabular}

A notable think can be identified (table 2) states that majority of the customers using e-banking services for doing online shopping. Whereas, "online trading and foreign exchange transfer" were the least preferred e-banking services which was also having significant influence in customers' perception in using e-banking services.

\section{Study Hypothesis}

$H_{0}$ : Customers were not significantly different in their perception towards various e-banking services among the groups of demographic variables.

As expected, customers were different in their perception in using e-banking services (f \& t test p value - Table 3 ) among the various groups of demographic variables except age and gender. The categories of demographic variables: Customers, who were doing business, who were highly educated, earn monthly income of Rs.50,000 - 1,00,000 had high mean score, where the significant value was less than 0.05 .

Hence all the discussed demographic variables statistically support the alternate hypothesis that "Customers were significantly different in their perception towards various e-banking services in terms of Educational qualification, income \& occupation of the customers.

A closer look at the above results explains that among the customers availing e-banking services; customers doing business, who were highly literate, drawing reasonable monthly income were highly influenced and satisfied towards e-banking services. On the other hand it could easily be understand that gender and age doesn't define the decision $f$ availing e-banking services.

TABLE - III Independent Sample T-test \& One Way ANOVA Test Statistics

\begin{tabular}{|c|c|c|c|c|c|}
\hline \multirow{2}{*}{$\begin{array}{l}\text { Demog } \\
\text { raphic } \\
\text { Profile }\end{array}$} & \multirow[b]{2}{*}{$\begin{array}{l}\text { Categories of } \\
\text { variables }\end{array}$} & \multicolumn{4}{|c|}{$\begin{array}{c}\text { Customers Perception -E-Banking } \\
\text { Services } \\
\end{array}$} \\
\hline & & Mean & $\mathbf{N}$ & $\mathbf{F} / \mathbf{T}$ & $\begin{array}{c}\text { Sig. } \\
\text { Valu } \\
\text { e }\end{array}$ \\
\hline \multirow{5}{*}{ Age } & Below 20 years & 31 & 24.55 & \multirow{5}{*}{$1.921 *$} & \multirow{5}{*}{.110} \\
\hline & $20-30$ years & 74 & 28.26 & & \\
\hline & $30-40$ years & 29 & 24.10 & & \\
\hline & $40-50$ years & 14 & 22.71 & & \\
\hline & Above 50 years & 2 & 26.50 & & \\
\hline \multirow{5}{*}{$\begin{array}{l}\text { Occupa } \\
\text { tion }\end{array}$} & Business & 66 & 27.44 & \multirow{5}{*}{$2.497 *$} & \multirow{5}{*}{.045} \\
\hline & $\begin{array}{l}\text { Government } \\
\text { employed }\end{array}$ & 18 & 24.44 & & \\
\hline & Retired & 8 & 16.50 & & \\
\hline & Private sector & 48 & 26.67 & & \\
\hline & Others & 10 & 25.90 & & \\
\hline \multirow{3}{*}{$\begin{array}{l}\text { Educat } \\
\text { ional } \\
\text { Qualifi } \\
\text { cation }\end{array}$} & Higher secondary & 27 & 20.52 & \multirow{3}{*}{$5.853^{*}$} & \multirow{3}{*}{.004} \\
\hline & Graduate & 89 & 27.20 & & \\
\hline & Post graduate & 34 & 27.85 & & \\
\hline \multirow[t]{4}{*}{ Income } & Below Rs. 25,000 & 48 & 23.17 & \multirow{4}{*}{$2.730 *$} & \multirow{4}{*}{.046} \\
\hline & Rs. $25,000-50,000$ & 57 & 26.63 & & \\
\hline & $\begin{array}{l}\text { Rs. } 50,000- \\
1,00,000\end{array}$ & 21 & 29.48 & & \\
\hline & Above Rs. $1,00,00$ & 24 & 28.04 & & \\
\hline \multirow[b]{2}{*}{ Gender } & Male & 83 & 26.07 & \multirow{2}{*}{$\begin{array}{c}-.103^{* *} \\
\text { (t-statisti } \\
\text { c) }\end{array}$} & \multirow[b]{2}{*}{.918} \\
\hline & Female & 67 & 26.23 & & \\
\hline
\end{tabular}

* F-Test statistics of one way ANOVA using SPSS

** Test statistics of Independent sample t test using SPSS

\section{A. From The Users of E-Banking Services}

Among the surveyed nationalized bank customers, most of the account holders use e-banking services (91\%) and the non-users accounts for only $9 \%$ of the customers (Table IV).

An interesting finding from the results (Table IV) that most of the customers preferring e-banking services for the purpose of making Online payment/purchase (43\%) and the prominent reason for their preference towards e-banking was time-saving (36\%). It can also be noted that nearly $38 \%$ of the customers expect facility to avail e-banking services in their regional languages and $20 \%$ of the users expect online customer feedback mechanisms which helps them to sort out the issues related in availing e-banking services.

Non-users opinion towards the e-banking services (Table V) revealed that out of 150 customers surveyed, only thirteen customers were non users of e-banking services. Among the thirteen, majority of the customers $76 \%$ were aware but they were not availing the e-banking services and stated the reasons that concern about the safety/security (36\%) and lack of technical knowledge $(31 \%)$ were the prominent reasons for not using the e-banking services. Likewise $46 \%$ of the non-users feel that creating awareness towards e-banking and hands on experience/training which is useful \& also encourage the customer to use the e-banking services.

\section{Published By:}

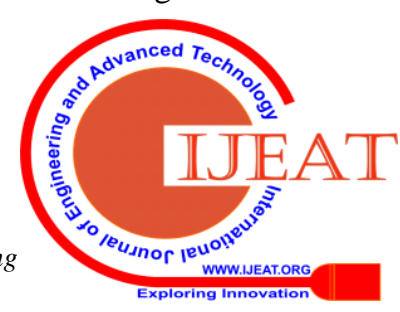


Table -IV Users Preference Towards E-Banking Services

\begin{tabular}{|c|c|c|}
\hline $\begin{array}{c}\text { Users Preference } \\
\text { towards e-banking } \\
\text { services } \\
(\mathrm{N}=150)\end{array}$ & Groups of the variables & $\begin{array}{l}\text { Percentage of } \\
\text { Respondents }\end{array}$ \\
\hline \multirow{2}{*}{$\begin{array}{l}\text { User of e-banking } \\
\text { services }\end{array}$} & Yes & $91 \%$ \\
\hline & No & $9 \%$ \\
\hline \multirow{5}{*}{$\begin{array}{l}\text { Purpose of using } \\
\text { E-banking }\end{array}$} & Business activity & $20 \%$ \\
\hline & $\begin{array}{l}\text { Online } \\
\text { payment/bills/purchase }\end{array}$ & $43 \%$ \\
\hline & Fund transaction & $21 \%$ \\
\hline & $\begin{array}{l}\text { View account statement / } \\
\text { Balance enquiry }\end{array}$ & $12 \%$ \\
\hline & Others & $3 \%$ \\
\hline \multirow{5}{*}{$\begin{array}{l}\text { Reason for preferring } \\
\text { e-banking services }\end{array}$} & $\begin{array}{l}\text { Access from anytime \& } \\
\text { anywhere }\end{array}$ & $22 \%$ \\
\hline & Time saving/speed & $36 \%$ \\
\hline & Customization & $18 \%$ \\
\hline & Ease of use & $11 \%$ \\
\hline & Trust/Safety & $4 \%$ \\
\hline \multirow{5}{*}{$\begin{array}{l}\text { Facilities expected by } \\
\text { users of e- banking } \\
\text { services }\end{array}$} & Better Network & $15 \%$ \\
\hline & Better security system & $16 \%$ \\
\hline & $\begin{array}{l}\text { Customer complaint } \\
\text { feedback mechanism }\end{array}$ & $20 \%$ \\
\hline & $\begin{array}{l}\text { Facility to avail e-banking } \\
\text { services } \\
\text { language }\end{array}$ & $38 \%$ \\
\hline & Reduce transaction fee & $11 \%$ \\
\hline
\end{tabular}

\section{B.From Non-Users of E-Banking Services}

Table -V Non Users Opinion Towards E-Banking Services

\begin{tabular}{|c|c|c|}
\hline $\begin{array}{l}\text { Non-Users } \\
\text { Opinion } \\
\text { towards } \\
\text { e-banking } \\
\text { services }\end{array}$ & Groups of the variables & $\begin{array}{c}\text { Percentage of } \\
\text { Respondents }\end{array}$ \\
\hline \multirow{2}{*}{$\begin{array}{c}\text { Aware about } \\
\text { the e-banking } \\
\text { services }\end{array}$} & Yes & $76 \%$ \\
\hline & No & $24 \%$ \\
\hline \multirow{4}{*}{$\begin{array}{l}\text { Reason for not } \\
\text { preferring } \\
\text { e-banking } \\
\text { services }\end{array}$} & $\begin{array}{l}\text { Unaware about the e-banking } \\
\text { services }\end{array}$ & $10 \%$ \\
\hline & $\begin{array}{l}\text { Concern about the safety } \\
\text { security(hacking) }\end{array}$ & $36 \%$ \\
\hline & $\begin{array}{l}\text { Comfortable with the } \\
\text { traditional banking }\end{array}$ & $23 \%$ \\
\hline & Lack of technical knowledge & $31 \%$ \\
\hline \multirow{3}{*}{$\begin{array}{c}\text { Factors } \\
\text { encourages the } \\
\text { customer to use } \\
\text { the e-banking } \\
\text { services }\end{array}$} & $\begin{array}{l}\text { Creating awareness towards } \\
\text { e-banking services (Advt, } \\
\text { Radio..) }\end{array}$ & $46 \%$ \\
\hline & Hands on experience/Training & $30 \%$ \\
\hline & $\begin{array}{l}\text { Educating the visiting } \\
\text { customers to banks }\end{array}$ & $24 \%$ \\
\hline
\end{tabular}

Non-users opinion towards the e-banking services (Table V) revealed that out of 150 customers surveyed, only thirteen customers were non users of e-banking services. Among the thirteen, majority of the customers $76 \%$ were aware but they were not availing the e-banking services and stated the reasons that concern about the safety/security $(36 \%)$ and lack of technical knowledge (31\%) were the prominent reasons for not using the e-banking services. Likewise $46 \%$ of the non-users feel that creating awareness towards e-banking and hands on experience/training which is useful \& also encourage the customer to use the e-banking services.

\section{RECOMMENDATIONS TO PRACTICE}

- Banks can take initiatives in providing customer education campaigns through communication media such as flyers, posters, hoardings radio, television, lectures, seminars, training camps and so on.

- Seems that only educated people who are handy with the technical aspects are availing the e-banking services the most often, hence it is important to inculcate the habit of using e-banking services for all, not only for the educated class. Banks shall organize training programmes and seminars to educate the customers regarding the use of e-channels.

- Most of the customers belongs to middle and senior age group, yet have faith in traditional banking system, hence it is also suggested to motivate and train professionals at the information centers at the bank to educate those age group customers' one who visits the banks in customer-preferred language regional languages which shall also be brought and make them the users of e-banking services.

- Banks shall have sound network security system, effective complaint feedback mechanism and availability of IT persons round the clock to meet out the expectations of customers and also to improve the usage of e-banking services.

\section{LIMITATIONS \& DIRECTIONS FOR FUTURE RESEARCH}

The scope of the present research is limited only to the customer's perception towards e-banking at the nationalized banks in Tamil Nadu. The results of the study have been identified on the basis of the one hundred and fifty surveyed customers who were sufficient to validate the findings but to generalize the results further; the study needs larger sample size. Further research under this context "prospects of e-banking services" may refine the findings by including customers from banks other than nationalized banks

\section{CONCLUSION}

Technological Development in India is continuously expanded at a remarkable rate. The on-going need to cope up with the technology in availing the offering bank products/services cannot be met without the initiatives of banker as well as the customers. By creating continuous focus on the prospects of e-banking channels effectively by the management of nationalised banks - the major player in banking sector will ensure not only the improvement in usage of e-banking services but also brings numerous benefits in leading a digitalised life in today's competitive world of technology. 


\section{REFERENCES}

1. Sharma, D., "India's leapfrogging steps from Bricks-and-Mortar to Virtual Banking: Prospect and Perils", IUP Journal of Management Research, 2009, vol. 8(3), pp.45-61.

2. Shamsher Singh, "Customer Perception of Mobile Banking: An Empirical Study in National Capital Region Delhi”, Journal of Internet Banking and Commerce, 2014, vol. 19(3), pp.1-22.

3. Rugimbana, R.,"Predicting ATM Usage: the Relative Importance of Perceptual and Demographic Factors", International Journal of Bank Marketing, 1995, vol.13(4), pp.18-31.

4. Mohammed, S. and Shariq, S, "A study of ATM usage in banks in Lucknow", International Journal of Engineering and Management Studies, 2011, vol. 2(1),pp. 47-53.

5. Abdul Hakkeem. $M$ and Moydheen Sha.Y, "An Empirical Study towards Customer Satisfaction in Internet Banking services with special reference to Tiruchirappalli District", International Journal of Scientific Research, 2015, vol. 4(5), pp. 3-5.

6. Kavitha \& Razia, "Factor Analysis of Customer Preference towards E -Banking Services with Special Reference to Coimbatore City", Indian Journal of Research, 2016, vol.5, pp. 363-364.

7. Shukla, R, "E-banking: Problems and Prospects", International Journal of Management \& Business Studies, 2011, vol. 1(1), pp. 23-25.

8. Yang, Z. Jun, M. \& Peterson, R.T. "Measuring Customer Perceived Online Service Quality", International Journal of Operation and Production Management, 2007, vol. 24(11), pp. 5-10.

9. Uppal, R.K. and Chawla, R. "E-Delivery Channel-Based Banking Services: An Empirical Study", The Indian Journal of Management Research, 2009, vol. 8(7), pp. 7-33.

10. Hari Mohan, Norani Ahmad, Quah Chi Kong, Chiam Tzeh Yew, Jimmy Liew, Nik Kamariah Nik Mat, "Determinants of the Internet Banking Intention in Malaysia", American Journal of Economics, 2013, vol.3(3), pp.149-152.

11. Kaur Jasveen \& Kaur Baljit, "Determining Internet Banking Service Quality \& Customer Satisfaction in India shows" Tenth AIMS International Conference on Management, 2013.

12. Fozia, "A Comparative Study of Customer Perception toward E-banking Services Provided By Selected Private \& Public Sector Bank in India, International Journal of Scientific and Research Publication, 2013, vol. 3(9), pp.1-5.

13. Raghavan, R.S, "Perception of Indian Banks in 2020", The Chartered Accountant, 2006, October issue, pp. 600-606.

\section{AUTHORS PROFILE}

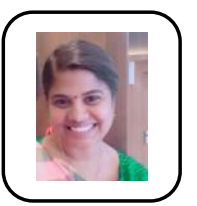

Dr.S.Priya Durga is an Assistant professor of Human Resource at Kalasalingam Academy of Research and Education, Krishnankovil. She has a strong academic background with a distinction in MBA and holds a Doctoral Degree from Anna University, Chennai in the area of Talent Retention. She has four years of teaching and research experience. She has published various research papers in peer reviewed journals and presented papers in conferences. She has organized training programmes on research methods and psychometric tools. 